\title{
ENVIRONMENTAL AND HEALTH IMPACT OF COAL USE FOR ENERGY PRODUCTION
}

\author{
By \\ El Safty A and Siha M \\ Department of Occupational and Environmental Medicine. \\ Cairo University. Egypt
}

\begin{abstract}
:
Introduction: Coal will continue to play a major role in the global energy system for the coming decades. Consideration of environmental issues are raised by many environmental protection bodies, health authorities and governments specially land use, air pollution, waste management and water management. Management of coal dust having heavy metals, gas emission carbon dioxide $\left(\mathrm{CO}_{2}\right)$, sulfur dioxide $\left(\mathrm{SO}_{2}\right)$ and nitrogen oxides (NOx), methane and ozone, also radiation are the primary area of concern to all environmental preservation bodies and governments. Climate change mitigation policies and measures may put stricter caps on emission of greenhouse gases. Among all industrial sources of air pollution, none poses greater risks to human health and the environment than coal-fired power plants. Health problems linked coal-fired power plants has been claimed for many deaths, cardiac diseases, asthma and cancers. Conclusion and recommendation: latest environmental and health assessment indicated that coal plant emissions of key particle-forming pollutants like $\mathrm{CO}_{2}, \mathrm{SO}_{2}$ and $\mathrm{NOx}$, methane, ozone and heavy metals over the last several years, contribute to a significant toll on health and longitivity of millions. Scientists in the field of health and environment declared their fear from using coal in energy production in Egypt as it may worsen quality of the environment and hence Egyptian health. After the Egyptian cabinet declaration ,in April 2014, of use of coal for energy production it worth mentioning that strict strategies should be followed for mitigating of coal's environmental impacts .
\end{abstract}

Key Words: Coal, Carbon dioxide, Sulphur dioxide, nitrous oxide, Greenhouse effect. 


\section{Introduction}

In recent years, the considerable increase in the price of crude oil and natural gas and concerns about their security of supply focused attention on whether fuel for power production could be obtained from the gasification of coal. Coal is by far the cheapest fossil fuel, costing around a third of the price of oil or natural gas per unit of energy produced.Coal-fired power plants currently fuel $41 \%$ of global electricity. In some countries, coal fuels a higher percentage of electricity.
Throughout history, coal has been used as an energy resource, for the production of electricity or heat, and is also used for industrial purposes as metals' refineries. Coal is the largest source of energy and is used as a solid fuel for the generation of electricity and heat through combustion worldwide, as well as one of the largest worldwide anthropogenic sources of carbon dioxide releases.

Coal is used either by gasification or liquefaction for production of syngas or synthetic fuels respectively that are equivalent to gasoline or diesel.

Table (1): Use of coal in electricity generation in different countries.

\begin{tabular}{|l|c|c|}
\hline \multicolumn{3}{|c|}{ Coal in Electricity Generation } \\
\hline South Africa 93\% & Poland 87\% & PR China 79\% \\
\hline Australia 78\% & Kazakhstan 75\% & India 68\% \\
\hline Israel 58\% & Czech Rep 51\% & Morocco 51\% \\
\hline Greece 54\% & USA 45\% & Germany 41\% \\
\hline
\end{tabular}

(http://www.worldcoal.org/coal/uses-of-coal/coal-electricity/) 
The use of coal for power generation is not exempt from environmental impacts and has been associated with a number of environmental challenges, primarily associated with air emissions.

Coal is a combustible black or brownishblack sedimentary rock composed mostly of carbon and hydrocarbons. Coal is a nonrenewable energy source because it takes millions of years to create. Coal is found in layers of rock that have been compacted and folded into mountains. Coal resources are fairly abundant throughout the world, though like any geologic resource, they aren't evenly distributed. The largest coal sources in the world appear in the United States, Russia, China, India, and Australia. Coal's abundance and ease of use make it an inexpensive fuel resource, particularly for developing nations that don't yet have fancy industrial refineries (http://www. dummies.com/how-to/content/what-is-theenvironmental-impact-of-mining-and-bur. html)

Coal is classified into four main types namely, anthracite, bituminous, subbituminous, and lignite. This classification depends on carbon content and the amount of heat production. The higher ranks of coal contain more heat-producing energy. Factors affecting the deposit of coal are summarized in the pressure and heat acting on the plant debris as it sank deeper and deeper over millions of years (http://www.eia.gov/energyexplained/ index.cfm?page=coal_home).

Anthracite accounts for less than $0.5 \%$ of the coal mined in the United States that are located in northeastern Pennsylvania and contains $86-97 \%$ carbon, and generally has a heating value slightly higher than bituminous coal.

Bituminous coal is the most abundant rank of coal found in the United States (about half of U.S production). West Virginia, Kentucky, and Pennsylvania are the largest producers of bituminous coal. It contains $45-86 \%$ carbon. Bituminous coal is used to generate electricity and is an important fuel and raw material for the steel and iron industries.

Subbituminous coal has a lower heating value than bituminous coal that contains $35-45 \%$ carbon and accounts for $44 \%$ of total USA production that is mainly in Wyoming.

Lignite is the lowest rank of coal, containing $25 \%-35 \%$ carbon, high moisture content, with the lowest energy content. There are 20 lignite mines in Texas and North Dakota in the United States, producing about $7 \%$ of U.S. coal. 


\section{Industrial process:}

Steam coal (Thermal coal) is used in power stations to generate electricity. Firstly, coal is milled to a fine powder, for faster burning ability and to increase the surface area. In these pulverised coal combustion (PCC) systems, the powdered coal is blown into the combustion chamber of a boiler and the produced hot gases convert water - in tubes lining the boiler into steam.

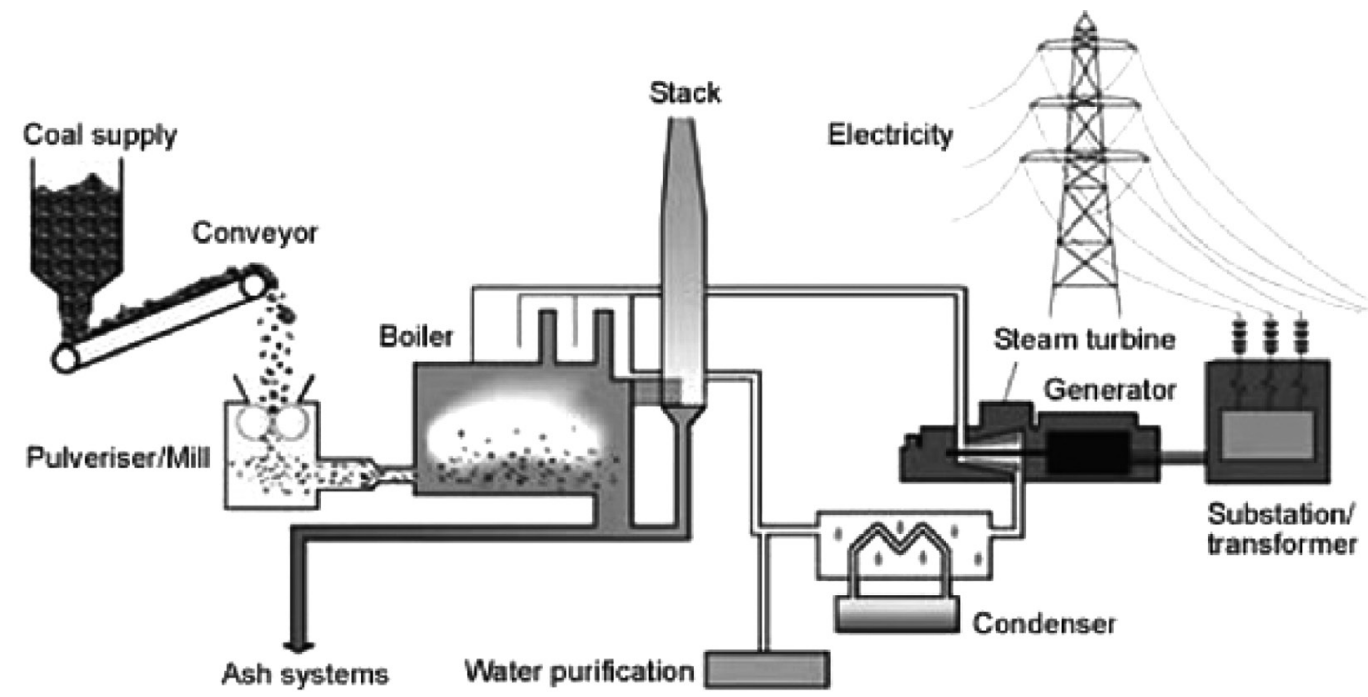

http://www.worldcoal.org/coal-the-environment/coal-use-the-environment/

$\mathrm{T}$ he high pressure steam is passed into a turbine containing thousands of propeller-like blades that rotate the turbine shaft at high speed. The generator consists of carefully wound wire coils that is mounted at one end of the turbine shaft. Electricity is generated when these wire coils are rapidly rotated in a strong magnetic field. After passing through the turbine, the steam is condensed and returned to the boiler to be heated once again.
The generated electricity is transformed into the higher voltages (up to 400,000 volts) used for economic, efficient transmission via power line grids, and it is transformed down to the safer 100-250 voltage systems for domestic uses.

The wet cooling used in coal-fired power stations, etc. emit drift and fog which are also environmental concern. The drift from the cooling towers is containing Respirable suspended 
particulate matter. http://en.wikipedia.org/ wiki/Environmental_impact_of_the_coal_ industry

When water used as a coolant is returned to the natural environment at a higher temperature, the change in temperature impacts organisms by decreasing oxygen supply, and affecting ecosystem composition. http://www.pollutionissues. com/Te-Un/Thermal-Pollution.html

Waste coal, also known as "culm," "gob," or "boney," is made up of unused coal mixed with soil and rock from previous mining operations. Runoff from waste coal sites can pollute local water supplies. http:// www.energyjustice.net/coal/wastecoal

During combustion of coal, there is emission of gases as $\mathrm{CO} 2$, oxides of sulfur (SO2), various oxides of nitrogen (NOx), hydrogen cyanide (HCN) and sulfur nitrate (SNO3) (Gabbard, 2008). Spontaneous combustion in stockpiles and waste piles causes emission of smoke and noxious fumes into the atmosphere (Dekok, 1986).

Carbon dioxide: Coal-fired power plants are responsible for one-third of America's carbon dioxide (CO2) emissions, making coal a huge contributor to global warming (Greenhouse effect) (Freese and Clemmer, 2006). The combustion of coal is the largest contributor to the humanmade increase of $\mathrm{CO} 2$ in the atmosphere (org/wiki/Earth\%27s _ http://en.wikipedia atmosphere). In 1999, world gross carbon dioxide emissions from coal usage were 8,666 million tons of carbon dioxide (International Energy Annual 2006).

Coal dust is the most evident environmental impact of coal powered industries. Dust can impact neighboring communities depending on wind direction, hence the importance of assessment of the place of these industries and effective mitigation measures. Electric generation using coal burning produces approximately twice the greenhouse gases per kilowatt compared to generation using natural gas. In 2011, utility coal plants in the United States emitted a total of 1.7 billion tons of $\mathrm{CO} 2$. A typical coal plant generates 3.5 million tons of $\mathrm{CO} 2$ per year (Hansen (2007).

In 2008 Kharecha and Hansen analyzed the effect of a coal phase-out on atmospheric $\mathrm{CO} 2$ levels. Their baseline mitigation scenario was a phase-out of global coal emissions by 2050. Due to ongoing business, atmospheric $\mathrm{CO} 2$ peaks at 563 parts per million (ppm) in the year 2100 .

In 2011, world gross emissions from coal usage were 14,416 million 
tonnes (International energy statistics. 2014). Coal-fired electric power generation emits around 2,000 pounds of carbon dioxide for every megawatt-hour generated that is almost double the release by a natural gas-fired electric plant. The policy adopted by the United States of increasing natural use for energy production, causes the fall of carbon dioxide emissions. The measurements in the first quarter of 2012 were the lowest of any recorded for the first quarter of any year since 1992 (Nuwer. 2012). In 2013, the head of the UN climate agency advised that most of the world's coal reserves should be left in the ground to avoid catastrophic global warming and to urgently transform industry and radically change to renewable energy. (http://www. theguardian.com/environment/2013/ nov/18/leave-coal-avoid-climatecatastrophe-un).

Sulfur Dioxide $\left(\mathrm{SO}_{2}\right.$ ) is released from burning coal that is oxidized to gaseous $\mathrm{H} 2 \mathrm{SO} 2$ causing widespread acidification of ecosystems, and scattering of solar radiation that exerts a cooling effect on climate, hence masking some of the warming caused by increased greenhouse gases (Crutzen and Lelieveld, 2001). Coal plants are the United States' leading source of SO2 that plays an important role on public health, and also contributes to the formation of small acidic particulates that can penetrate into human lungs and be absorbed by the bloodstream. Sulfur dioxide also causes acid rain, which can damage crops, forests, and soils, and acidifies lakes and streams. A typical uncontrolled coal plant emits 14,100 tons of SO2 per year. A typical coal plant with emissions controls, including flue gas desulfurization (smokestack scrubbers), emits 7,000 tons of SO2 per year.

Nitrogen oxides (NOx) pollution causes ground level ozone, or smog, which can burn lung tissue, exacerbate asthma, and make people more susceptible to chronic respiratory diseases. A typical uncontrolled coal plant emits 10,300 tons of NOx per year. A typical coal plant with emissions controls, including selective catalytic reduction technology, emits 3,300 tons of NOx per year.

In case of cooling towers in power stations, with sea water makeup, sodium salts are deposited on nearby lands which would convert the land into alkali soil by reducing the fertility of vegetative lands and also cause corrosion of nearby structures.

Calcium Oxide: Another environmental impact of use of coal in Coalfired boilers / power plants on water quality when using coal or lignite rich in limestone is the production of ash containing calcium oxide $(\mathrm{CaO})$. $\mathrm{CaO}$ readily dissolves in 
water to form slaked lime / $\mathrm{Ca}(\mathrm{OH}) 2$ and carried by rain water to rivers / irrigation water from the ash dump areas. Lime softening process precipitates $\mathrm{Ca}$ and $\mathrm{Mg}$ ions / removes temporary hardness in the water and also converts sodium bicarbonates in river water into sodium carbonate that reacts with the remaining $\mathrm{Ca}$ and $\mathrm{Mg}$ removing water hardness. Thus river water is converted into soft water that when used in irrigation converts the fertile soils into alkaline sodic soils (http://www. gewater.com/handbook/ext_treatment/ ch_7_precipitation.jsp)

Pollutants emitted by burning coal include fine particulates (PM2.5) and ground level ozone. Every year, the burning of coal without the use of available pollution control technology causes thousands of preventable deaths in the United States. Particulate matter (also referred to as soot or fly ash) can cause chronic bronchitis, aggravated asthma, and premature death, as well as haze obstructing visibility. A typical uncontrolled plan emits 500 tons of small airborne particles each year. A study commissioned by the Maryland nurses association in 2006 found that emissions from just six of Maryland's coal-burning plantscaused 700deaths peryearnationwide, including 100 in Maryland. (http://www. nytimes.com/2012/01/06/business/energy- environment/constellation-energy-coalcompany-urges-stricter-pollution-rules. html?_r=1\&). Studies have shown that exposure to particulate matter is related to an increase of respiratory and cardiac mortality (Lockwood et al, 2009)

Burning coal is also a leading cause of smog, acid rain, and toxic air pollution. Some emissions can be significantly reduced with readily available pollution controls, but most U.S. coal plants have not installed protection technologies.

Coal also contains low levels of Uranium, Thorium, and other naturally occurring radioactive isotopes that may contaminate the surrounding environment. When coal is burned, the fly ash contains uranium and thorium "at up to 10 times their original levels (Hvistendahl, 2007). Coal plants emit radiation in the form of radioactive fly ash which is inhaled and ingested by neighbors, and incorporated into crops. A 1978 paper from Oak Ridge National Laboratory estimated that coal-fired power plants of that time may contribute a whole-body committed dose of $19 \mu \mathrm{Sv} / \mathrm{yr}$ to their immediate neighbors in a $500 \mathrm{~m}$ radius (McBride et al., 1978).

The United Nations Scientific Committee on the Effects of Atomic Radiation's 1988 report estimated the committed dose $1 \mathrm{~km}$ away to be $20 \mu \mathrm{Sv} /$ 
yr for older plants or $1 \mu \mathrm{Sv} / \mathrm{yr}$ for newer plants with improved fly ash capture, but was unable to confirm these numbers by test. $\mathrm{Su}$ in his report (2006) declared that coal-plants carry more radioactive wastes into the environment than nuclear plants producing the same amount of energy. Also Hvistendahl ,2007 approved the same fact and declared that plant-emitted radiation carried by coal-derived fly ash delivers 100 times more radiation to the surrounding environment than does the normal operation of a similarly productive nuclear plant .

Coal and coal waste products (including fly ash, bottom ash and boiler slag) releases approximately 20 toxicrelease chemicals, including arsenic, lead, mercury, nickel, vanadium, beryllium, cadmium, barium, chromium, copper, molybdenum, zinc, selenium, radium, which are dangerous if released into the environment. While these substances are trace impurities, enough coal is burned that significant amounts of these substances are released (Gabbard, 2008). If 100 tons of waste coal are burned, 85 tons will remain as waste coal ash http://www.energyjustice. net/coal/wastecoal/.

Pollutants emitted annually from a typical, uncontrolled coal plant include approximately: 114 pounds of lead, 4 pounds of cadmium, other toxic heavy metals, and trace amounts of uranium. Baghouses can reduce heavy metal emissions by up to 90 percent, 720 tons of carbon monoxide( which causes headaches and places additional stress on people with heart disease), 220 tons of hydrocarbons, volatile organic compounds (VOC), which form ozone, 225 pounds of arsenic, which will cause cancer in one out of 100 people who drink water containing 50 parts per billion (Nescaum, 2011) (http://www. ucsusa.org/clean_energy/coalvswind/c02c. html)

Mercury emission from coal burning are concentrated in the food chain and are converted into methylmercury harming both wildlife and people who consume freshwater fish (Brighamet al, 2003). Power plants are responsible for half of the mercury emissions in the United States (EPA, 2011). A typical uncontrolled coal plants emits approximately 170 pounds of mercury each year.

\section{Health Impact due to Coal Exposure:}

Air pollutants released from smoke stacks of coal-fired power stations constitute the largest health risk for the general public in comparison to emissions to the water or soil. They cause both acute and chronic health effects. Communities in the proximity of coal power plants sometimes experience a much higher 
exposure to certain airborne pollutants. The major fraction of the air pollution, however, is transported over long distances and thus impacts a much bigger proportion of the population, by increasing the background levels of ambient air pollution.

The health damage caused by coal combustion is not limited to the proximity of the power plant, as the exhaust cloud from the smokestack can be transported up to several hundred kilometers and across borders, until pollutants deposit in ecosystems or in people's lungs. The height of smokestacks and wind conditions determine where pollution is transported. Up to $10 \mathrm{~km}$ away from the plant, coarse particulates (PM10), nitrogen oxides, sulphur dioxide, acid gases, persistent organic pollutants, heavy metals and dioxins can be transported. However trans-boundary travel occur with sulfur dioxide, nitrogen oxides, volatile organic compounds (VOCs), heavy metals, dioxins, fine particulates (PM 2.5). Global contamination up to $1000 \mathrm{~km}$ is documented also with fine particulate matter (PM2.5), mercury and dioxins (Wenig et al., 2003).

Significant evidence exists on how long-term exposure to these air pollutants affects the lungs and the heart. They include chronic respiratory diseases, such as chronic bronchitis, emphysema and lung cancer, and cardiovascular diseases, such as myocardial infarctions, congestive heart failure, ischemic heart disease and heart arrhythmias. Acute effects include respiratory symptoms, such as chest tightness and coughing, as well as exacerbated asthma attacks. Children, older people and patients with an underlying condition are more susceptible to these effects. Recent research suggests that air pollution may also result in low birth weight and pre-term delivery as a result of maternal exposure during pregnancy (European Commission, HEALTH-EU website).

Special concern arises from the large mercury emissions from coal power plants as mercury can impair the cognitive development of children and cause irreversible damage to vital organs of the fetus file://C:/Users/Sony/Downloads/ heal_report_the_unpaid_health_bill_-_ how_coal_power_plants_make_us_sick_ finalpdf\%20(1).pdf

According to a report published by NBC news in 2004, coal-fired power plants shorten nearly 24,000 lives a year in the United States (2,800 from lung cancer). In the United States, the United States Environmental Protection Agency (EPA) estimates that a range of 13,000 to 34,000 preventable deaths will be avoided by the 
reductions in PM2.5 and ozone, that is expected by the end of the years needed to complete implementation of the coal plant cleanup provisions of the Final Cross-State Air Pollution Rule. The Final Cross-State rule is estimated to prevent 15,000 additional (non-fatal) heart attacks, 19,000 attacks of acute bronchitis; 420,000 upper and lower respiratory symptoms, 400,000 aggravated asthma attacks; and 19,000 hospital and ER visits (e.g., for asthma attacks triggered by soot from coal burning). By reducing such health detriments there is expected reduction of work or school. (http://www.nbcnews.com/ id/5174391/\#.U2onkbsU_IU).

Dated back to 1967 a study was performed by Hassenien and his coauthors in Masr El Kadima factory in Egypt, for animal coal, where the main operation is carbonization of animal bones. The total working population was 185 laborers and they were mostly complaining of cough (80.5\%), dyspnea (47\%), and wheeze (42\%). Radiological findings revealed coal miner's pneumoconiosis in $28.1 \%$ of the studied population. Another study by Abo
El Ata et al (2000) evaluated environmental and respiratory health among 228 coal miners at North Saini (Maghara coal mine). Total respirable and non-respirable dust particles proved to exceed the TLVs. Clinical study demonstrated $40 \%$ affection of the studied group, however chest $\mathrm{x}$ rays showed $25 \%$ affected personnel.

In 2008 the World Health Organization (WHO) and other organizations calculated that coal particulates pollution cause approximately one million deaths annually across the world, that is approximately one third of all premature deaths related to all air pollution sources (Shrader-Frechette, 2011).

\section{The Economics of Health Impacts from Coal Power Generation:}

The external costs caused by coal power plants in terms of harm to human health and the environment are not included in the price for electricity. A recent report by the European Environment Agency (EEA 2011) found that the largest share of damage to health and the environment from industrial air pollution in Europe came from power plants. 
Table 2: Health impacts and attributed costs from coal power generation in the EU (2009)

\begin{tabular}{|l|c|c|}
\hline Health impact & $\begin{array}{c}\text { Burden associated with coal } \\
\text { power generation in the EU } \\
(2009)\end{array}$ & $\begin{array}{c}\text { Attributed costs } \\
\text { ( } \square \text { million per year) }\end{array}$ \\
\hline $\begin{array}{l}\text {-Chronic mortality } \\
\text { (premature deaths, VSL) } \\
\text { - Chronic mortality (life } \\
\text { years lost, VOLY) }\end{array}$ & 18,247 & 37,954 \\
- Chronic bronchitis & 196,218 & 10,596 \\
- Hospital admissions \\
(respiratory and \\
cardiovascular) \\
- Restricted activity days \\
(working age \\
population) \\
- Lost working days \\
- Respiratory medication \\
use \\
- Lower respiratory \\
symptoms
\end{tabular}

file://C:/Users/Sony/Downloads/heal_report_the_unpaid_health_bill_-_how_coal_ power_plants_make_us_sick_finalpdf\%20(1).pdf 
Egypt's cabinet on April 2014 approved the use of coal for power generation after a fierce debate within the government over whether the highly pollutant fuel should be permitted for use by the energy-intensive cement industry (http://www.reuters.com/ article/2014/04/02/us-egypt-energy-coalidUSBREA3117Y20140402).

Conclusion: From the previous history and researches we advised that the decision of using coal as source of energy in power plants should be cautiously issued. High effective technologies have been developed to tackle environmental challenges, including the release of pollutants - such as carbon dioxide, methane, oxides of sulphur and nitrogen and particulate and trace elements, such as mercury. More recently, the focus has been on developing and deploying technologies to tackle greenhouse gas emissions associated with the use of coal. The determining factors for these emissions are coal characteristics and power plant efficiency.

An increase in coal utilization for energy generation is not a safe option in view of current levels of air pollution and the impacts on health. It is necessary to be able to assess the performance of a coal plant, continuous monitoring of emissions that must be maintained below legislated limits
Environmentalists and health concerned scientists declared that the use of coal as energy would be an additional source of environmental pollution in Egypt, which already has one of the worst pollution levels in the world.

Recommendations: A number of environmental technologies varies substantially and are available to mitigate environmental impact. The technology selected for a power plant will vary depending on its specific characteristics such as location, age, and fuel source. The key strategy in the mitigation of coal's environmental impacts is to improve the energy efficiency of power plants. Efficient plants burn less coal per unit of energy produced and consequently have lower associated environmental impacts. Efficiency improvements, particularly those related to combustion technologies, are an active area of research and an important component of a climate change mitigation strategy.

\section{References}

1. Abo El Ata GA, El Beshlawy MS, El Kholy BM, Bassioni M and Gaafar S (2000): Environmental journal of Occupational Medicine; 24(1): 89115 .

2. Brigham ME, Krabbenhoft DP and Hamilton PA (2003): «Mercury in stream ecosystemsnew studies initiated by the U.S. Geological Survey». US Geological Survey.

3. Crutzen PJ and Lelieveld J (2001): Human Impacts on Atmospheric Chemistry, by, Annual 
Review of Earth and Planetary Sciences, 29: 17 -45 .

4. Dekok D (1986): David, Unseen Danger: A Tragedy of People, Government and the Centralia Mine Fire. University of Pennsylvania Press. ISBN 978-0-8122-8022-7.

5. EEA (2011): http://www.env-health.org/IMG/ pdf/heal_report_the_unpaid_health_bill_-_ how_coal_power_plants_make_us_sick_ finalpdf.pdf

6. EPA (Environmental Protection Agency) (2011): First National Standards for Mercury Pollution from Power Plants: Historic mercury and air toxics standards meet 20-year-old requirement to cut dangerous smokestack emissions, EPA.

7. European Commission, HEALTH-EU website http://ec.europa.eu/health-eu/health_problems/ cardiovascular_diseases/index_en.htm

8. Freese B and Clemmer S (2006): «Gambling with Coal: How New Climate Laws Will Make Future Coal Plants More Expensive,» Union of Concerned Scientists; p 2.http://www. sourcewatch.org/index.php/Environmental_ impacts_of_coal\#cite_ref-thermal_27-0

9. Gabbard A (2008): «Coal Combustion: Nuclear Resource or Danger». Oak Ridge National Laboratory. Retrieved 2008-10-22.

10. Hansen J (2007): «Testimony of James E. Hansen at Iowa Utilities Board» (PDF). Columbia University.

11. Hassenein M, El Sayed M and AbdEl Shafi $H$ (1967): The effect of animal coal dust on the laborers working in this industry. MD. Thesis. Department of Industrial medicine and occupational Diseases. Faculty of Medicine. Cairo University. Egypt.

12. Hvistendahl M (2007): «Coal Ash Is More Radioactive than Nuclear Waste: Scientific American», Scientific American, Nature America, Inc.13.http://www.sourcewatch. org/index.php/Environmental_impacts_of_ coal\#Cost_of_environmental_damages_from_ coal_plants
13. IEA (International Energy Annual) (2006): Energy Information Administration. 2008. Archived from the original on 23 May 2011.

14. IES (International energy statistics) (2014): U.S. Energy Information Administration.

15. Kharecha PA and Hansen JE (2008): «Implications of «peak oil» for atmospheric $\mathrm{CO} 2$ and climate». Global Biogeochem. Cycles 22: GB3012. arXiv:0704.2782. B i b c ode : 2008 G B i o C . .22 .3012 K. doi:10.1029/2007GB003142.

16. Lockwood A, Welker-Hood K, Rauch M and Gottlieb B (2009):»Coal>s Assault on Human Health» Physicians for Social Responsibility Report.http://www.sourcewatch.org/index.php/ Environmental_impacts_of_coal\#Cost_of_ environmental_damages_from_coal_plants

17. McBride J P, Moore R E, Witherspoon J P and Blanco R E (1978): «Radiological impact of airborne effluents of coal and nuclear plants.» Science; 202(4372): 1045

18. NBC News 2004: http://www.nbcnews.com/ id/5174391/\#.U2onkbsU_IU

19. Nescaum (2011): Control Technologies to Reduce Conventional and Hazardous Air Pollutants from Coal-Fired Power Plants.

20. Nuwer R (2012): A 20-Year Low in U.S.Carbon Emissions. blogs.nytimes.com http://www. theguardian.com/environment/2013/nov/18/ leave-coal-avoid-climate-catastrophe-un

21. Shrader-Frechette K (2011): What Will Work: Fighting Climate Change with Renewable Energy, Not Nuclear Power, Oxford University Press, 9, ISBN 0-19-979463-4.

22. Su S (2006): TAD Source Term and Dose Rate Evaluation. Bechtel Saic. 000-30R-GGDE00100-000-00A. Retrieved 20 May 2012.

23. United Nations Scientific Committee on the Effects of Atomic Radiation (1988): «Annex A». Sources, Effects and Risks of Ionizing Radiation. New York: United Nations. 83. ISBN 92-1-142143-8.

24. Wenig M, Spichtinger N, Stohl A, et al. (2003): Intercontinental transport of nitrogen oxide 
pollution plumes. Atmospheric Chemistry and Physics, 2003, 3:387393, http://www.atmoschem-phys.net/3/387/2003/acp-3-387-2003.pdf -http://www.dummies.com/how-to/content/what-isthe-environmental-impact-of-mining-and-bur.html -http://www.epa.gov/airquality/powerplanttoxics/ index.html

-http://www.eia.gov/energyex plained/index . cfm?page=coal_home.

-http://www.reuters.com/article/2014/04/02/usegypt-energy-coal-idUSBREA3117Y20140402

-http://www.nytimes.com/2012/01/06/business/ energy-environment/constellation-energy-coalcompany-urges-stricter-pollution-rules.html?_ $\mathrm{r}=1 \&$

-http://www.worldcoal.org/coal-the-environment/ coal-use-the-environment/
-http://org/wiki/Earth\%27s

- http://en.wikipedia atmosphere

-http://en.wikipedia.org/wiki/Environmental_ impact_of_the_coal_industry

-http://www .pollutionissues.com/Te-Un/ThermalPollution.html

-http://www.energyjustice.net/coal/wastecoal/

-http://www.worldcoal.org/coal/uses-of-coal/coalelectricity/

-file://C:/Users/Sony/Downloads/heal_report_the_ unpaid_health_bill_-_how_coal_power_plants_ make_us_sick_finalpdf\%20(1).pdf

-http://www.gewater.com/handbook/ext_treatment/ ch_7_precipitation.jsp

-http://www.ucsusa.org/clean_energy/coalvswind/ c02c.html 